\title{
Looking for the Essay: \\ A Journey of Rediscovery
}

In 2009, in The Personal Camera, Laura Rascaroli observed that the essay film was usually confused with several other types of films, which it contained, up to some extent, but to which it could not be reduced. For example, it could not be synonymous with documentary film, because it conveyed a "message" (i.e., a thesis) but was not conditioned by external phenomena (hence not bound by any truth claims). It was not synonymous with political cinema either; although it contained a strong authorial position meant to trigger "thought" (i.e., a reflection) in the viewers, this acted more on a metacritical and formal level than anything else. Rascaroli noted disapprovingly that the expression "essay film” was unduly used to describe all non-commercial cinema, experimental films, or simply those deemed unclassifiable by analysts and commentators. The conclusion to be drawn from this position is that, for all its creativity and free form, there is a line that the essay film must not cross.

Roughly a decade later, in How the Essay Film Thinks (2017), Rascaroli revised her position entirely, claiming: "The moment of the essay film,

Fátima CHINITA

Lisbon Polytechnic Institute

chinita.estc@gmail.com

EKPHRASIS, 2/2021

THE ESSAY FILM

As SElF-Representational Mode pp. 5-9

DOI: 10.24193/ekphrasis.26.1

Published First Online: December 15, 2021 then, is politically inflected not only because the essay gives voice to the need for independent critical expression, if utopian only [e.g., non-fictional works on post-colonialism, feminism, LGBT rights, etc., which would often be censured in other contexts], but also because it is constitutively against its time" (5). Such an idea lies at the core of Nora M. Alter's position on this film genre, in The Essay Film After Fact and Fiction (2018). For this theorist there is no essay film without ideology, be it political or artistic, an aspect which cannot be 
contextually reduced to the Western European essay film practice from the 1960s to the 1990s, marked by a direct answer to contemporary events of the day (143). That period was fertile in aesthetic experimentation as well as political radicalism and served as an alternative to the deficient treatment of some subjects by the media: "A number of events in the second half of the twentieth century elicited strong reactions in which the essay film was used as a medium for protest, resistance, witness, or commentary.” (148).

This is reinforced in the increasingly transnational theoretical output on the essay film, for example, World Cinema and the Essay Film, edited by Brenda Hollweg and Igor Krstić (2019). Tellingly, the subtitle of the collection edited by Elizabeth A. Papazian and Caroline Eades (2016) is Dialogue, Politics, Utopia and besides openly political overtones-such as those contained in Mauro Resmini's approach of Nanni Moretti's Marxist ideologyit also engages with a theoretical trend that perceives the essay film as increasingly nearing either the documentary or the fictional film. Concerning the latter cinematic category, for example, Timothy Corrigan - in line with what he believed in 2011, when he wrote about "refractive cinema" - considers self-reflexive digressions a form of thinking (cf. "Essayism and Contemporary Film Narrative" 15-27) and Rick Warner draws on a rather paradigmatic narrative device: the shot/countershot juxtaposition. More recently, in Vassilieva and Williams' edited collection Beyond the Essay Film (2020), Rascaroli herself advocates in favor of the lyric essay which goes against the "essay's characteristic rationalism." (75).

Thus, apparently, as one can see by this rather cursory overview of books published in English, ${ }^{1}$ not only is the essay film a hard genre to grasp, and so unclassifiable that it might not be a genre at all-there are no core exclusive characteristics to it—, but it is evolving and transmuting into something else (cf. book review on Beyond the Essay Film, in this issue). How can what is not graspable in the first place turn into something different? Here is a conundrum, if ever there was one. Commentators on this subject usually agree upon the tentative nature of this definition and the probatory character of the activity (and the resulting artefacts).

The present issue of Ekphrasis, on the essay film as a self-representational mode, is no exception to this exploratory rule. Its several contributions all undertake a personal search or evince a search undertaken by others. From the highly solipsistic or diaristic version of the essay film to the more socially-oriented one, there is one thing that all of these articles have in common: a metaphorical (sometimes even literal) voyage of discovery. Therefore, the

1 In French there are several publications on the essay film. The collection edited by Suzanne Liandrat-Guigues and Murielle Gagnebin, L'Essai et le cinéma (published in 2004) is a precursor to some of the ideas put across in the other outlets, namely the notion that the essay film thinks and that it is an open and creative a form of in-betweenness posed at the confluence of fiction and documentary. 
contributors embark on a (re)search: be it for themselves and their identity; for their artistic practice or the technological-aesthetic affordances of their medium; or the social conditions of their environment and the world in general. In true dialogical form they write themselves through others: their selection of case studies and subjects reveals probably as much about themselves as the circumstances and the artist(s) they write about, proving, if proof were necessary, that the essay film is as much an inward impetus as an outwards move.

Thus, the essay film is a dialogical and creative expressive form of communication. It might be impossible to define it further, but this is enough to see what remains of Rascaroli's 2009 claim. Nowadays, the essay film is more hybrid than ever and the added cross-pollinations it has been subjected to-as a result of cinema intermingling with other art forms and using new digital and more versatile technologies - has, for whatever reason, yielded a stronger and more democratic urge to express oneself and always for an audience. To appropriate a term in current cybernetic use, the essay film has gone viral (to the point of encompassing global internet distribution of self-made films, as much as home movies recorded on smartphones documenting (self-)confinement as result of COVID-19) The essay film need not even be physically produced in film any longer, spreading to videographic criticism, the academic equivalent of audiovisual self-expression through others, and to the space of the gallery in multi-channel installations such as the ones our invited contributor, Mieke Bal, produces.

Contrary to Rascaroli's 2009 assertion, the essay film has now spread to other domains; it is no longer confused with them, it has become them. Likewise, it is also a new challenge to define essay film by what it is not, because it appears to be everything and everywhere. Could it be that essay film (the noun and genre) is being replaced by "essayism" (the adverb and the reflective, and often disruptive, activity)? In any event, it seems that the essay film is being substituted by what I term the "audiovisual essay," a general expression fit for all purposes and accommodating equally well both cinematic and videographic efforts, endowed with very different materialities and artistic languages. Engaging with the title of the collection edited by Julia Vassilieva and Deane Williams, one could say that Beyond the Essay Film, lies the audiovisual essay in all its array of possibilities.

Mieke Bal's text, a true first-person account written in essay form, presents the thought processes of the artist who classifies her films as "theoretical fictions" (cf. www.miekebal.org) and advocates self-representation through collective work and expression. The other contributors who, in true essayistic fashion, have been granted the freedom to express themselves in their preferred version of English (British or American) all draw on filmic examples and audiovisual practices, which reveals an engagement with cinema as much as with the world.

The present issue of Ekphrasis starts off with personal modalities of search which have been brought into the field of the audiovisual essay from other areas of knowledge: psychology, ethnography and archiveology. Kyle Barrett writes about the cinephilic self-search of Irish 
filmmaker Mark Cousins, undertaken as a meandering journey or its arrest; Mark Readman examines John Burgan's identity quest in Germany in the historically-charged context of the fall of the Berlin Wall; Vladimir Rosas-Salazar addresses archival materials as a way to reconstruct effaced memories from victims of the Chilean dictatorship. In the latter case the medium is both expressive and reconstructive after the fact, enabling a cathartic effect for those involved in the memory-erasing process and its reconstruction via several audiovisual sources. In the following section of the issue, Muriel Tinel-Temple proves that the essay and its materiality may be the vehicle to reconstruct personal experiences both as catharsis and artistic self-expression through the amassed data provided by found footage. Liri Chapelan deals with the digital versatility of the audiovisual media as an artistic escape from confinement and its opportunity (in this particular case, for artists) to communicate with other subjects in the same situation through the use of distribution platforms, transforming the essay into a trans-geographical act. Cristian Eduard Drăgan elaborates on the video essay used for non-academic and didactic purposes, as a tool for users' self-reference. Teresa Lima focuses not on the users, but on the film viewers and their dialogic relationship with the apparatus in an essay film by Portuguese filmmaker Edgar Pêra dealing with just such a phenomenon from an eminently sensorial perspective. In section three of this issue of Ekphrasis Elke Möller, Mihai Dragolea and Doru Pop commit themselves to analyzing the work of filmmakers with a strong ideological bias: Liwaa Yazji, the Syrian filmmaker that returns to her devastated home country in order to make the film Haunted / Maskoon so that she may convey the trauma of war as a healing instrument; Copel Moscu, the Romanian film director who defied communist censorship through dissidence and subversiveness; and his countryman Radu Jude, whose fictional film Bad Luck Banging or Loony Porn / Babardeală cu bucluc sau porno balamuc (winner of this year's Berlin International Film Festival) is the corollary of his essayistic practices.

\section{Works Cited}

Alter, Nora M. The Essay Film After Fact and Fiction. Columbia University Press, 2018.

Corrigan, Timothy. The Essay Film: From Montaigne After Marker. Oxford University Press, 2011.

-. "Essayism and Contemporary Film Narrative." The Essay Film: Dialogue, Politics, Utopia, edited by Elizabeth A. Papazian and Caroline Eades, Wallflower Press, 2016, pp. 15-27.

Hollweg, Brenda, and Igor Krstić, editors. World Cinema and the Essay Film: Transnational Perspectives on a Global Practice. Edinburgh University Press, 2019.

Liandrat-Guigues, Suzanne, and Murielle Gagnebin, editors. L'Essai et le cinéma. Éditions Champ Vallon, 2004.

Papazian, Elizabeth A., and Caroline Eades, editors. The Essay Film: Dialogue, Politics, Utopia. Wallflower Press, 2016. 
Rascaroli, Laura. The Personal Camera: Subjective Cinema and the Essay Film. Wallflower Press, 2009.

-. How the Essay Film Thinks. Oxford University Press, 2017.

—. "Compounding the Lyric Essay Film: Towards a Theory of Poetic Counter-Narrative." Julia Vassilieva and Deane Williams, editors, Beyond the Essay Film: Subjectivity, Textuality, and Technology. Amsterdam University Press, 2020, pp. 75-93.

Resmini, Mauro. "What Does It Mean Today to Be Communist?': Nanni Moretti's Palombella rossa and La cosa as Essay Films." The Essay Film: Dialogue, Politics, Utopia, edited by Elizabeth A. Papazian and Caroline Eades, Wallflower Press, 2016, pp. 192-215.

Vassilieva, Julia, and Deane Williams, editors. Beyond the Essay Film: Subjectivity, Textuality, and Technology. Amsterdam University Press, 2020.

Warner, Rick. "Essaying the Forms of Popular Cinema: Godard, Farocki and the Principle of Shot/ Countershot.” The Essay Film: Dialogue, Politics, Utopia, edited by Elizabeth A. Papazian and Caroline Eades, Wallflower Press, 2016, pp. 29-67. 